\title{
A másodlagos hypogammaglobulinaemia, a fertőzések és a halálozás összefüggései és a preventív immunglobulin-pótlás szülkségessége krónikus lymphoid leukaemiás betegekben
}

\author{
Losonczy Hajna dr. - Nagy Ágnes dr. - Kosztolányi Szabolcs dr. \\ Tóth Orsolya dr. - Csalódi Renáta dr. \\ Hussain Alizadeh dr. - Szomor Árpád dr.
}

Pécsi Tudományegyetem, Általános Orvostudományi Kar, Klinikai Központ, I. Belgyógyászati Klinika, Hematológiai Tanszék, Pécs

\begin{abstract}
Krónikus lymphoid leukaemiában szenvedő 186 betegnél vizsgáltuk az immunstatust 2012. január és 2015. március között. Elemeztük az infekciók előfordulását, a mortalitást azoknál, akik nem részesültek profilaktikus immunglobulin-kezelésben. Az immunglobulin-G (IgG)-szint a betegek 62,37\%-ában normális (7-17,8 g/1), 35,48\%-ában csökkent volt, néhány esetben mértünk magas immunglobulinszintet $(2,15 \%)$. Az elörehaladottabb betegségstádiumokban (Rai-stádium) egyre alacsonyabbak az immunglobulinszintek. Ezzel fordított arányban növekedtek a fertőzések. A hypogammaglobulinaemia jelenléte fontosabb volt a fertőzés kialakulásának szempontjából, mint a betegség progressziója. A leggyakoribb infekció a felső légúti fertőzés $(33,07 \%)$ és a szepszis $(18,90 \%)$ volt. A kemoterápia után két hónappal a kezdetben normális immunglobulinszint átlagosan 21\%-kal csökkent, ugyanakkor emelkedett az infekciók kialakulása. A leggyakoribb halálok a szepszis volt: 30\% alacsony immunglobulinszint mellett, illetve $20 \%$ normális immunglobulinszintnél. A krónikus lymphoid leukaemiás és immunhiányos betegeknél mind a morbiditás, mind a mortalitás csökkentésére az irodalom szerint indokolt a profilaktikus immunglobulin-kezelés. Az irodalmi ajánlások szerint a súlyos vagy közepesen súlyos, visszatérő bakteriális infekció esetén a hypogammaglobulinaemiát korrigálni kell. Az immunglobulin-profilaxis lehet kis dózisú ( $10 \mathrm{~g})$, fix adagú ( $18 \mathrm{~g})$ vagy betegre szabottan nagyobb dózisú (300-400 mg/ttkg). Az intravénás kezelés 3 hetente minimum 6 hónapig ajánlott, az immunglobulinszint folyamatos ellenórzése mellett. Az ajánlás szerint a nagyobb dózisú, 6 alkalommal 3 hetente adott profilaktikus, személyre szabott immunglobulin-infúzió effektívebb és költséghatékony. Ezzel a dózissal az ismétlődő infekcióban szenvedő betegek $50 \%$-át fertőzésmentesen lehet tartani.
\end{abstract}

Orv Hetil. 2019; 160(38): 1487-1494.

Kulcsszavak: krónikus lymphoid leukaemia, másodlagos immundeficientia, az immunglobulin-profilaxis hatékonysága

Correlations between secondary hypogammaglobulinaemia, infections and mortality and the need for preventive immunoglobulin replacement in patients with chronic lymphoid leukaemia

Immune status was investigated in 186 patients with chronic lymphoid leukaemia between January 2012 and March 2015. Incidences of infections and mortality were analysed in patients who did not receive prophylactic immunoglobulin therapy. Immunoglobulin G ( $\mathrm{IgG}$ ) levels were normal $(7-17.8 \mathrm{~g} / \mathrm{L}$ ) or decreased in $62.37 \%$ and $35.48 \%$ of patients, respectively. We measured high immunoglobulin levels only in a few cases $(2.15 \%)$. Immunoglobulin levels became increasingly lower in more advanced disease stages (Rai stages). The number of infections was inversely proportional to that. Hypogammaglobulinaemia proved to be more important than disease progression in terms of the 
development of infections. The most common infections were upper respiratory tract (33.07\%) and sepsis (18.90\%). Two months after chemotherapy, initially normal immunoglobulin levels decreased by an average of $21 \%$, and at the same time the incidence of infections increased. The most common cause of death was sepsis: $30 \%$ occurred at low immunoglobulin levels, while $20 \%$ at normal immunoglobulin levels. According to literature, prophylactic immunoglobulin treatment is indicated in patients with chronic lymphoid leukaemia and immunodeficiency for decreasing both morbidity and mortality. According to recommendations in literature, replacement treatment must be administered in severe or moderately severe recurrent bacterial infections. Immunoglobulin prophylaxis may be provided as low dose $(10 \mathrm{~g})$, fix dose ( $18 \mathrm{~g}$ ) or individually customized higher dose $(300-400 \mathrm{mg} / \mathrm{kg}$ body weight) treatment. According to recommendations, higher dose immunoglobulin prophylaxis, administered every three weeks on six occasions, is more efficient when customized. With this dose, infection-free condition may be achieved in $50 \%$ of patients.

Keywords: chronic lymphoid leukaemia, secondary immune deficiency, efficacy of immunoglobulin prophylaxis

Losonczy H, Nagy Á, Kosztolányi Sz, Tóth O, Csalódi R, Hussain A, Szomor Á. [Correlations between secondary hypogammaglobulinaemia, infections and mortality and the need for preventive immunoglobulin replacement in patients with chronic lymphoid leukaemia]. Orv Hetil. 2019; 160(38): 1487-1494.

(Beérkezett: 2018. október 24.; elfogadva: 2019. március 8.)

\section{Rövidítések}

$\mathrm{ATM}=$ (ataxia telangiectasia, mutated $)$ ataxia telangiectasia, mutált; CHOP = ciklofoszfamid + adriamicin + vinkrisztin + prednizolon; $\mathrm{CLB}=$ klorambucil; $\mathrm{CLL}=$ (chronic lymphoid leukaemia) krónikus lymphoid leukaemia; CVP = ciklofoszfamid + vinkrisztin + prednizolon; Cyclo $=$ ciklofoszfamid; $\mathrm{F}=$ fludarabin; FC = fludarabin + ciklofoszfamid; Ig = immunglobulin; IgA = immunglobulin- $\mathrm{A} ; \operatorname{IgG}=$ immunglobulin- $\mathrm{G}$; $\mathrm{IgVH}=$ (immunoglobulin variable region heavy chain $) \mathrm{az} \mathrm{im-}$ munglobulin-nehézlánc gén variábilis régiója; IVIG = (intravenous immunoglobulin) intravénás immunglobulin; MabCamp $=$ MabCampath (alemtuzumab); $\mathrm{NK}=$ (natural killer cell) természetes ölősejt; R-Benda = rituximab + bendamusztin; R$\mathrm{CLB}=$ rituximab + klorambucil; $\mathrm{R}-\mathrm{CVP}=$ rituximab-ciklofoszfamid + vinkrisztin + prednizolon; $\mathrm{RFC}=$ rituximab + fludarabin + ciklofoszfamid

A CLL az indolens non-Hodgkin-lymphomák közé tartozik, az összes leukaemia 25-30\%-át teszi ki a kaukázusi populációban. Az időskor betegsége, a diagnózis idején a medián életkor 67-72 év. Nagyobbrészt férfiakon alakul ki (a nemzetközi irodalom szerint a férfi/nő arány általában 2/1). Incidenciája: 3-5/100 000 lakos/év. Magyarországon kb. évi 300-500 új beteggel lehet számolni. A CLL-t jellemzi a kis, viszonylag érett B-lymphocyták proliferációja és akkumulációja a csontvelóben, a vérben, a lymphoid szervekben, a májban és más szervekben. A CLL lefolyása változatos képet mutat, a túlélés hónapoktól évtizedekig tarthat [1].

Az infekciók szerepéról a morbiditást és a mortalitást illetően már 1939-ben Wintrobe és Hasenbush [2] közölte, hogy a CLL-betegek 38,2\%-ában fejlődött ki infekció, mely $66,7 \%$-ban okozta a betegek halálát. A súlyos fertőzés kockázata $26 \%$ /5 év, és a halálozás $1 / 3$-a ezzel függ össze. Az infekciók lehetnek enyhék, közepesen súlyosak és nagyon súlyosak, 50\%-ban recidiválhatnak.
A betegség előrehaladtával komplex - humorális és celluláris - immundefektus alakul ki. Kóros a humorális immunválasz, melynek oka a hypogammaglobulinaemia, elsősorban az IgG-, de az IgA-szint is csökkent. A humorális immunitás zavarát okozza, hogy csökkent a normális B-sejtek száma, ezért kóros a B-sejt-funkció. Csökken a T-sejtek CD4/CD8 aránya, a T-helper-funkció, az NK-sejt és az NK-funkció is. A dendritikus sejtek elégtelen múködésének következtében kóros a makrofágok antigénprezentációja, és csökken a fagocitózis is. Mindezek miatt jön létre az immunvédekezés komplex zavara. A komplementrendszer tagjait és funkcióit illetően is csökkenés alakul ki $[3,4]$.

A neutropenia a betegség előrehaladott stádiumában jelenik meg. A T-sejt és a B-sejt kölcsönhatása nem müködik. A nem mutált IgVH-statusú betegek (50\%) túlélése szignifikánsan rövidebb, mint akiknek mutált az IgVH-statusa. Nagy rizikót jelent az előrehaladott betegségstádium, a kezelések tovább fokozzák az immunszuppressziót. A nagy rizikójú citogenetikai abnormalitások, mint a dell7p, a dell lq és a komplex citogenetikai abnormalitások, melyek rezisztensek az alkilálószerekre, a purinanalógokra és a monoklonális anti-CD20-antitestekre, nehezítik a kezeléseket, ezért jelentősen hozzájárulnak az infekciók számának és recidívájának növekedéséhez $[5,6]$.

Az utóbbi 10 évben nagy előrehaladás történt a betegség kezelésében, mint például az immunkemoterápia bevezetése fitt betegek esetében. Eddig a legsikeresebbnek az RFC-terápia bizonyult. Az általános válaszarány igen magas, 95\%, a komplett remisszió is magas, $44 \%$. Az RFC standard kezelésnek számít, de alkalmazásakor számolni kell a fokozott infekcióhajlammal [3].

Az utóbbi 5 évben teljesen új utak nyíltak meg a CLL kezelésében. Ilyen a B-sejtek jelátviteli rendszerének, például a Bruton-tirozinkináz funkciójának gátlása kis 
1. táblázat |A vizsgált betegek kor szerinti megoszlása

\begin{tabular}{lcc}
\hline Kor $($ év $)$ & Betegszám & $\%$ \\
\hline$<55$ & 14 & 8 \\
$55-64$ & 34 & 18 \\
$65-74$ & 62 & 33 \\
$>75$ & 76 & 41 \\
\hline Összesen: & 186 & 100 \\
\hline
\end{tabular}

2. táblázat |A Rai-stádiumok

\begin{tabular}{lll}
\hline Rai-stádium & Tünetek & Túlélés (év) \\
\hline 0. & $\begin{array}{l}\text { Csak lymphocytaszám-növekedés } \\
\text { van. Lymphocyta: több mint } 15 \times\end{array}$ & $>15$ \\
& $10^{9} / 1$ & \\
& Megjelennek a nyirokcsomók & 9 \\
I. & $\begin{array}{l}\text { Máj- és lépmegnagyobbodás van } \\
\text { jelen }\end{array}$ & 5 \\
II. & Vérszegénység $($ Hgb<1lg/1) & 2 \\
III. & $\begin{array}{l}\text { Csökkent thrombocytaszám } \\
\left(<100 \times 10^{9} / 1\right)\end{array}$ \\
IV. & & 2 \\
\end{tabular}

molekulákkal: ibrutinib, idelaliszib, venetoklax (mely más mechanizmussal hat, az apoptózist fokozza úgy, hogy akadályozza az apoptózist gátló $\mathrm{Bcl}-2$ fehérje funkciót). Az új szerek adhatók monoterápiaként, kombináltan, vagy CD20-ellenes antitestekkel és kemoterápiával is (például bendamusztin). Ennek ellenére a CLL még ma is gyógyíthatatlan betegségnek számít [7].

A jelen munkában felmértük CLL-betegeink immunstatusát, a másodlagos hypogammaglobulinaemia következményeit, az infekciók előfordulását, valamint ezek kimenetelét és hatását a mortalitásra.

\section{Célkitüzés}

Vizsgáltuk, hogy a különböző mértékű immunglobulinszint-csökkenés mennyire befolyásolja a betegek morbiditását és mortalitását.

\section{Módszer}

2012. január és 2015. március között 446 alkalommal történt immunglobulin-meghatározás klinikánkon 186 betegnél. Vizsgáltuk a fertőző betegségek típusait, a kórokozókat, az alkalmazott kezeléseket és hatásaikat a mortalitásra.

A vizsgált betegek kor szerinti eloszlását mutatja az 1 . táblázat. A legfiatalabb beteg a diagnózis idején 32 éves,

3. táblázat $\mid$ A betegek medián életkora, nem szerinti megoszlása, klinikai stádiumai, rizikófaktorok, genetikai abnormalitások

\begin{tabular}{lc}
\hline Medián életkor (év) & $65(32-92)$ \\
A nemek megoszlása (férfi/nő, \%) & $52 / 48$ \\
\hline Rai-stádium (\%) & \\
-0. & 32,74 \\
- I. & 22,20 \\
- II. & 17,71 \\
- III. & 7,62 \\
- IV. & 19,73 \\
\hline CD38 & $(\%)$ \\
- Negatív <30\% & 51,81 \\
- Pozitív >30\% & 48,19 \\
\hline Genetikai abnormalitások & $(\%)$ \\
- del 11q (ATM) & 63,64 \\
- del 17p (p53) & 27,28 \\
- del 13q14 & 4,54 \\
- Egyéb & 4,54 \\
\hline
\end{tabular}

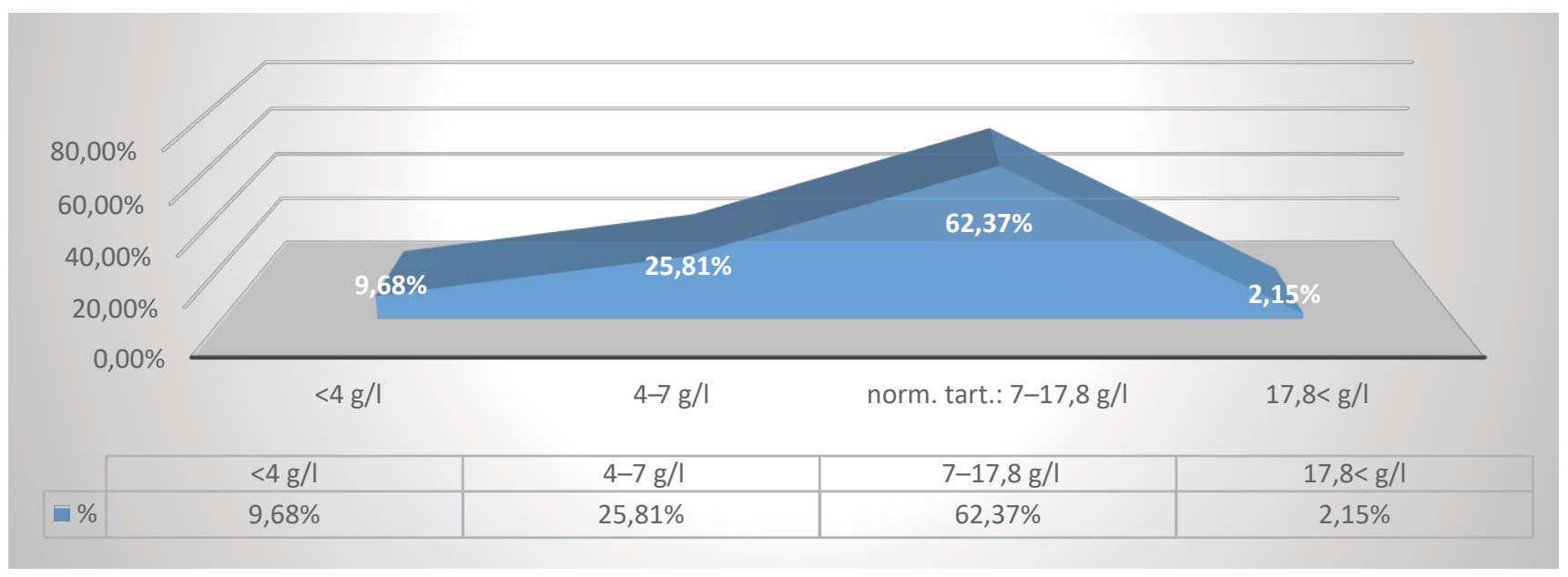

1. ábra Az IgG-értékek \%-os eloszlása CLL-ben
IgG = immunglobulin-G; CLL = krónikus lymphoid leukaemia 


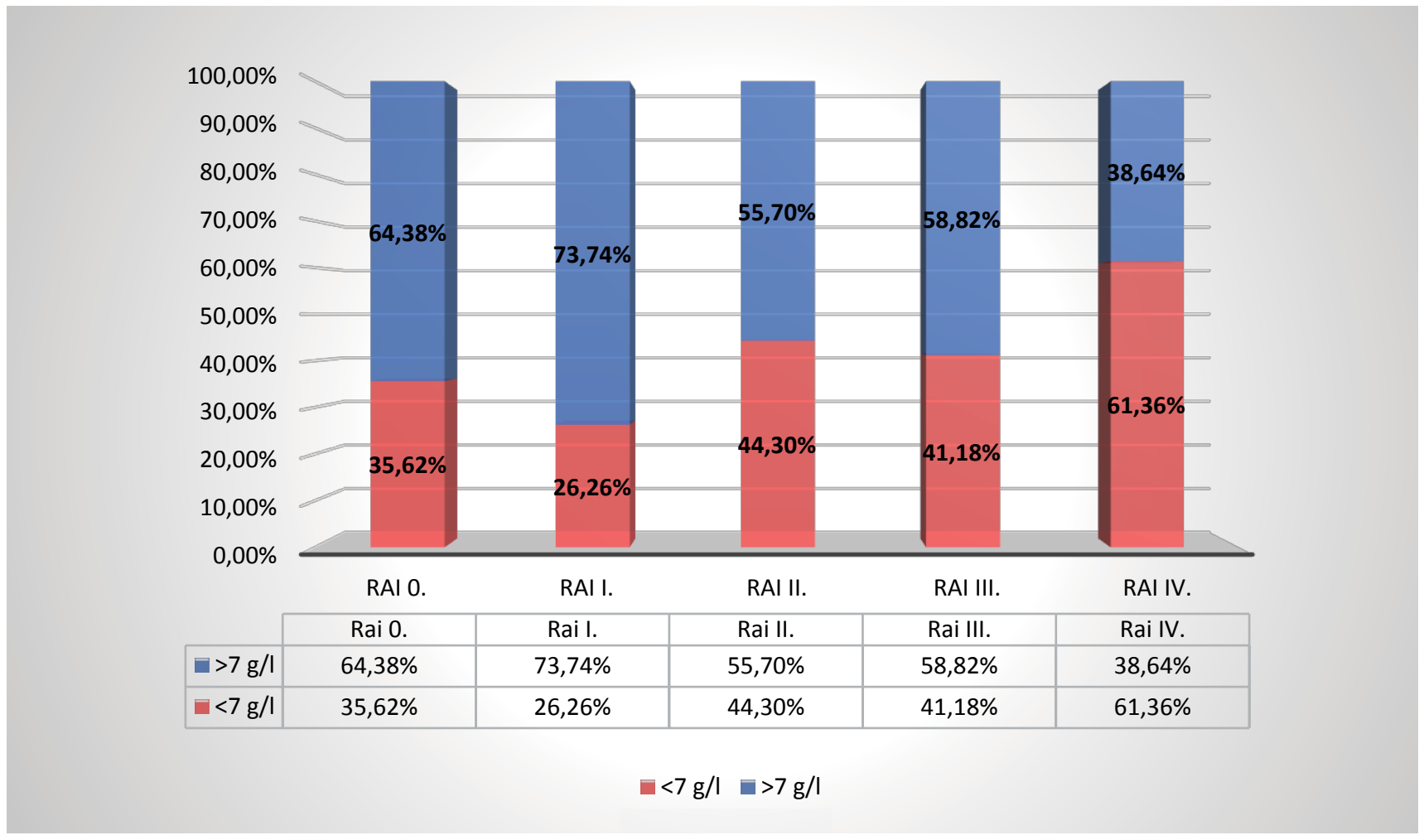

2. ábra

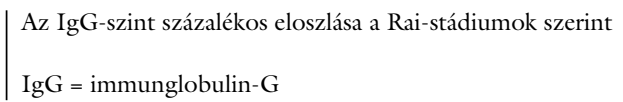

a legidősebb 92 éves volt. Átlagéletkor a diagnózis idején: 65 év. A diagnózis idején a betegeknél 62,37\%-ban normális volt az IgG-szint (1. ábra).

A 2. táblázat mutatja a betegség Rai-stádiumait. A 3. táblázat foglalja össze a betegek legfontosabb demográfiai adatait, kedvezőtlen rizikófaktorait, mint a lymphocyták CD38 tirozin-kináz fokozott expresszióját és a genetikai abnormalitásokat, melyek miatt a két tumorszuppresszor gén múködésképtelenné válik. Az egyik a dell7p (melynél TP53-mutáció vagy -deletio vagy mindkettő mutatható ki), a másik a delllq abnormalitása, mely az ATM-gén deletióját hozza létre.

A betegek 15,8\%-ában TP53-mutáció fordul elő, amelynek a fele $17 \mathrm{p}$-deletiót is mutat. A két forma vizsgálatakor a TP53-defektus 25,4\%-ban volt kimutatható. A tanulmány azt mutatta, hogy a TP53-mutáció eredménye fontosabb, mint a deletio. Ahol TP53-mutációt analizáltak, ott addicionálisan $10 \%$ magas rizikójú beteget ismertek fel [8].

Részletesebben ábrázoljuk az IgG-szinteket Rai-stádiumok szerint (2. ábra). A normális IgG-szint (7-17,8 g/1) Rai 0. és I. stádiumban fordult elő a legtöbb esetben. A Rai II. stádiumtól a betegek IgG-szintje fokozatosan csökkent, a legalacsonyabb a Rai IV-es stádiumban volt. A betegség progressziójával csökken a normális immunglobulinszinttel rendelkező betegek aránya.

Érdekesnek tűnik, hogy a fertőzéseket az alacsony IgG-szint jobban fokozza, mint az előrehaladottabb
Rai-stádium (4. táblázat). Alacsony IgG-szintnél minden Rai-stádiumban magasabb volt az infekciók aránya.

$\mathrm{Az}$ is kérdés volt, hogy a citosztatikus kezelés milyen mértékben befolyásolja az immunglobulinszintet. Az első vonalban adott citosztatikus kezeléseket az 5. táblázatban ábrázoljuk.

Látható, hogy a leghatékonyabbnak tartott kezelést, az RFC-t a betegek kb. fele kapta meg. A kezelések után 2 hónappal határoztuk meg ismét az IgG-szinteket. Kiderült, hogy a kezelés az IgG-szintet jelentősen csökkentette, a kezelés után az átlagos immunglobulinszint 21\%kal alacsonyabb volt. Ezzel fordított arányban emelkedtek az infekciók.

4. táblázat |A fertőzések és a Rai-stádiumok összefüggése

\begin{tabular}{lcc|cc}
\hline & \multicolumn{2}{c|}{$\begin{array}{c}\text { Alacsony IgG-szint } \\
(<7 \mathrm{~g} / \mathrm{l})\end{array}$} & \multicolumn{2}{c}{$\begin{array}{c}\text { Normális IgG-szint } \\
(7-17,8 \mathrm{~g} / \mathrm{l})\end{array}$} \\
\hline & $\begin{array}{c}\text { Van fertőzés } \\
(\%)\end{array}$ & $\begin{array}{c}\text { Nincs } \\
\text { fertózés }(\%)\end{array}$ & $\begin{array}{c}\text { Van fertózés } \\
(\%)\end{array}$ & $\begin{array}{c}\text { Nincs } \\
\text { fertózés }(\%)\end{array}$ \\
\hline Rai 0. & 6,04 & 1,65 & 8,79 & 15,38 \\
Rai I. & 4,4 & 2,75 & 6,04 & 10,99 \\
Rai II. & 5,49 & 1,1 & 4,4 & 6,04 \\
Rai III. & 2,75 & 0,55 & 3,85 & 0,55 \\
Rai IV. & 10,44 & 1,1 & 5,49 & 2,2 \\
\hline
\end{tabular}

IgG = immunglobulin-G 
5. táblázat | Citosztatikus kezelések az első vonalban

\begin{tabular}{lcc}
\hline Kezelések & Esetszám & $\%$ \\
\hline RFC & 27 & 44,3 \\
FC & 9 & 14,8 \\
CLB & 9 & 14,8 \\
Cyclo & 6 & 9,8 \\
F & 2 & 3,3 \\
R-Benda & 2 & 3,3 \\
R-CVP & 2 & 3,3 \\
MabCamp & 1 & 1,6 \\
R-CLB & 1 & 1,6 \\
CVP & 1 & 1,6 \\
CHOP & 1 & 1,6 \\
\hline
\end{tabular}

CHOP = ciklofoszfamid + adriamicin + vinkrisztin + prednizolon; CLB = klorambucil; CVP = ciklofoszfamid + vinkrisztin + prednizolon; Cyclo = ciklofoszfamid; $\mathrm{F}=$ fludarabin $; \mathrm{FC}=$ fludarabin + ciklofoszfamid; MabCamp = MabCampath (alemtuzumab); R-Benda $=$ rituximab + bendamusztin; R-CLB = rituximab + klorambucil; $\mathrm{R}-\mathrm{CVP}=$ rituximab-ciklofoszfamid + vinkrisztin + prednizolon; $\mathrm{RFC}=$ rituximab + fludarabin + ciklofoszfamid

Megvizsgáltuk, hogy milyen mértékben alakultak ki fertőzések, és ez hogyan függ össze az immunglobulinszinttel (3. ábra). Látható, hogy a nagyon alacsony $(<4$ $\mathrm{g} / \mathrm{l}$ ) és az alacsony (4-7 g/l) IgG-szintek mellett nagy eséllyel kaptak a betegek (88,89 és 77,08\%-ban) különböző fertőzéseket. Normális (7-17,8 g/1) IgG-szintnél 44,83\%-ban alakult ki fertőzés. Az IgG-szint emelkedésével a fertőzések száma jelentősen csökken. Magas IgGszint 15 esetben volt (486 mérésből), melyek közül 6 esetben volt fertőzés. Dominálnak a bakteriális fertőzések, 80,73\%-ban, a vírusok jóval ritkábban, 13,76\%-ban,
6. táblázat |A fertőzések helyei

\begin{tabular}{lc}
\hline A fertőzések helyei & $\%$ \\
\hline Felső légúti fertőzés & 33,07 \\
Szepszis & 18,90 \\
Alsó légúti fertőzés & 11,02 \\
Bőrgyógyászati fertőzések & 7,09 \\
Központi idegrendszer fertőzései & 2,36 \\
Húgyúti fertőzések & 1,57 \\
Gastrointestinalis fertőzések & 0,79 \\
Egyéb & 25,20 \\
\hline
\end{tabular}

a gombás fertőzések pedig 0,9\%-ban fordultak elö; 4,59\%-ban a fertőzések oka ismeretlen maradt.

A fertőzések típusai a következők voltak: a legnagyobb arányban légúti fertőzések fordultak elő, felső légúti 33,07\%-ban, alsó légúti fertőzések 11,02\%-ban alakultak ki. Ezután sajnos a szeptikus megbetegedések következtek 18,90\%-ban. Az egyes szervek fertőzéseit felsorolva láthatjuk a táblázatban: a bőrgyógyászati, a központi idegrendszeri, a húgyúti és a gastrointestinalis fertőzések követik egymást (6. táblázat).

A mortalitás és az immunglobulinszintek összefüggését mutatja be a 4 ábra. A vizsgált időszakban 30 halott volt, ez a betegek 16\%-a. Az IgG-szint csökkenésével a halálozási arány jelentősen megnövekszik.

A leggyakoribb halálok a szepszis, mely alacsony immunglobulinszintnél 30,0\%, a normális immunglobulinszintnél 20,0\% volt (7. táblázat).

Eredmények: A hypogammaglobulinaemia kialakulása nagyobb jelentőséggel bírt a fertőzés szempontjából, mint a betegség progressziója. Az előrehaladottabb stá-

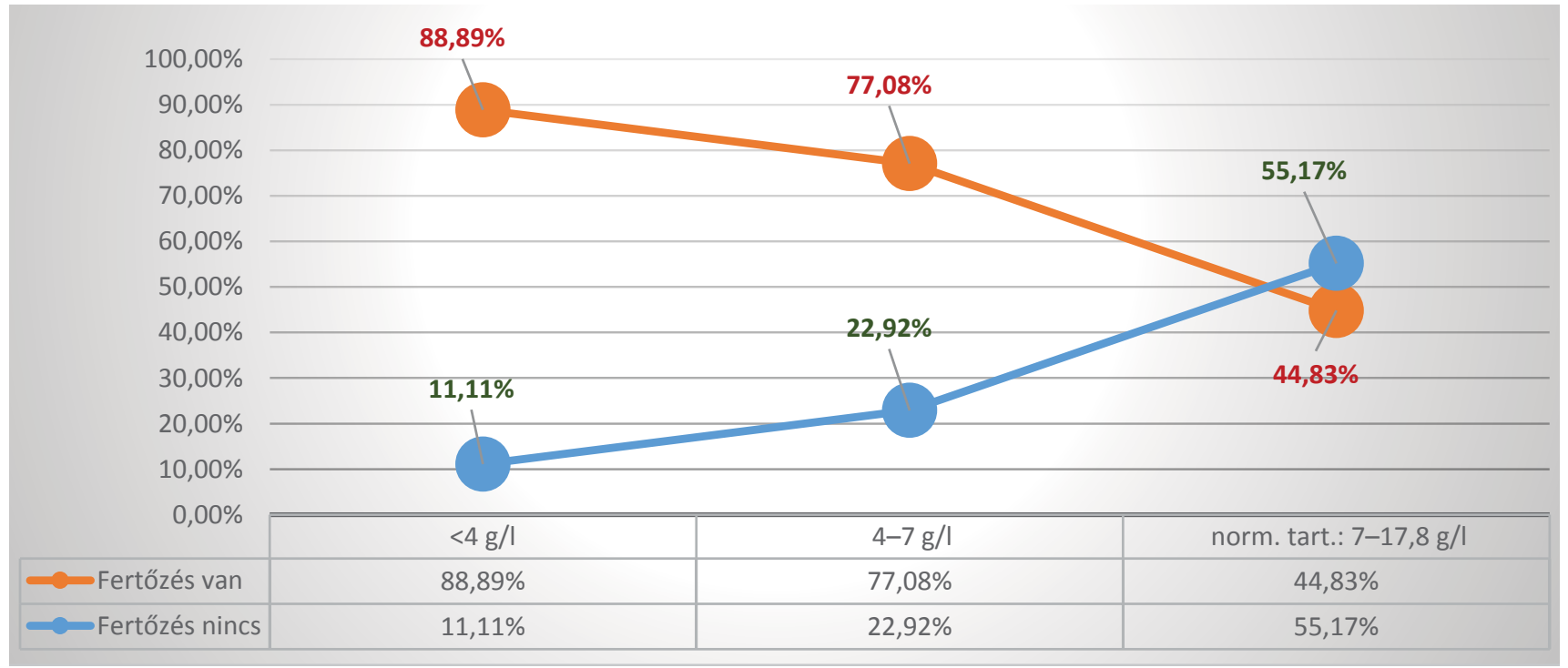

3. ábra $\mid \begin{aligned} & \text { A fertőzések \%-os eloszlása az IgG-értékek változása szerint } \\ & \text { IgG = immunglobulin-G }\end{aligned}$ 


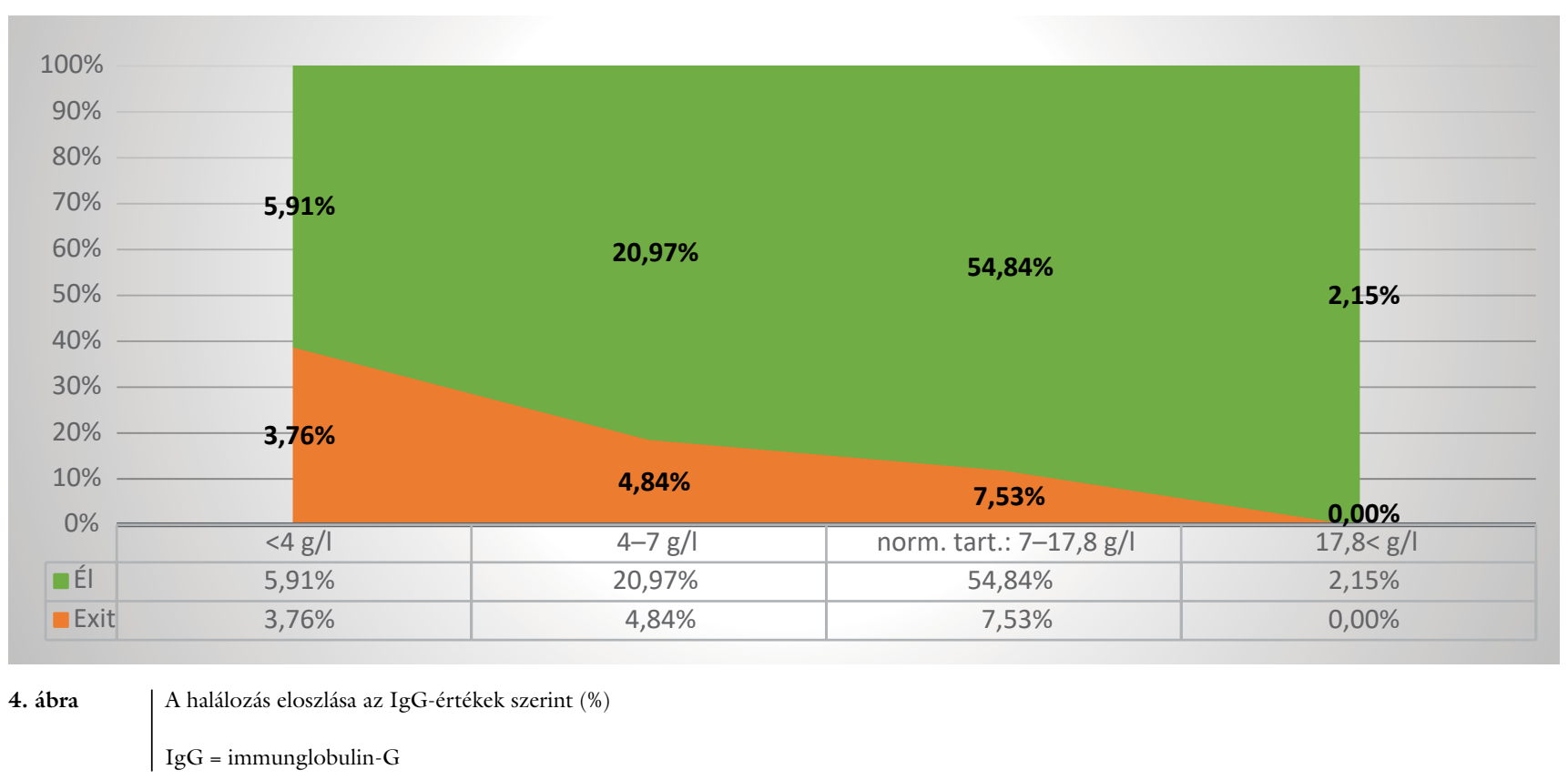

diumokban egyre alacsonyabbak az immunglobulinszintek. Az immunglobulinszint csökkenését befolyásolta a citosztatikus kezelés is. Az infekciók kialakulása gyakrabban fordult elő az immunglobulin-szérumkoncentráció csökkenésével.

Az infekciók kivédésére három vitatott módszer lehetséges:

a) antimikrobás profilaxis,

b) vakcináció,

c) immunglobulin-pótlás profilaktikus céllal.

\section{Következtetés}

A közleményben bemutatott statisztikai adatok alapján egyértelmúen látszik, hogy alacsony szérum-IgG-szint és társuló infekciók esetén az IVIG-pótlás indokolt, de

7. táblázat |A halál okai

\begin{tabular}{lcc}
\hline A halálozás* okai & $\begin{array}{c}<7 \text { g/l (alacsony } \\
\text { IgG-szint) }\end{array}$ & $\begin{array}{c}>7 \text { g/l (normál } \\
\text { IgG-szint) }\end{array}$ \\
\hline Szepszis & $30,00 \%$ & $20,00 \%$ \\
Szív- és keringési rendszeri & & $7,50 \%$ \\
megbetegedések & & \\
Anémia & $5,00 \%$ & $5,00 \%$ \\
Tüdótumor & $5,00 \%$ & $2,50 \%$ \\
Tüdőgyulladás & & $5,00 \%$ \\
Veseelégtelenség & $2,50 \%$ & \\
A CLL progressziója & & $2,50 \%$ \\
Egyéb & $10,00 \%$ & $5,00 \%$ \\
\hline
\end{tabular}

*A halálozás okairól csak abban az esetben tudtunk, ha az esetet vizsgálták a PTE Kórbonctanon.

IgG = immunglobulin-G; PTE = Pécsi Tudományegyetem mi a teendő a normális szérum-IgG-szint ellenére ismétlődő infekciók esetén vagy nagyon alacsony szérumIgG-szinttel rendelkező betegnél, ha nincs infekciója? Véleményünk szerint normál IgG-szintek ellenére is lehet csökkent az immunválasz, hiszen az IgG-t termelő B-sejtek malignus megbetegedésével állunk szemben. Ilyen esetekben érdemes további immunológiai vizsgálatokat végezni, kórokozó-specifikus antitestszinteket is mérhetünk. Ez utóbbiak esetében az úgynevezett tesztimmunizáció nyújthat további segítséget. Ez azt jelenti, hogy például Pneumococcus elleni poliszacharid antigént tartalmazó oltóanyaggal immunizáljuk a beteget, és az oltást követő 40. napon meghatározzuk a kórokozó-specifikus IgG-szintet. Abban az esetben, ha nem kapunk megfelelő antitestválaszt, betegünk fokozottan veszélyeztetett az infekciókkal szemben, és indokolt az IVIGpótlás. Amennyiben igen alacsony IgG-szintet mérünk, de a betegnek még nem volt infekciója, akkor ennek ellenére is indokolt az IVIG-pótlás megkezdése, mert a primer immundeficiens betegek gondozása kapcsán szerzett tapasztalatok azt mutatják, hogy ilyen esetekben akár az első infekció is lehet végzetes a beteg számára.

Mind a morbiditás, mind a mortalitás csökkentésére egyértelmúen indokolt a profilaktikus immunglobulinkezelés [9-12]. Az irodalmi ajánlások szerint a súlyos vagy közepesen súlyos, visszatérő bakteriális infekció esetén a hypogammaglobulinaemiát normalizálni kell. Az immunglobulin-profilaxis lehet kis dózisú, fix dózisú vagy betegre szabottan nagyobb dózisú intravénás kezelés 3 hetente minimum 6 hónapig, folyamatos immunglobulinszint-ellenőrzés mellett. Ezzel a dózissal az ismétlődő infekcióban szenvedő betegek $50 \%$-át infekciómentesen lehet tartani [13].

$\mathrm{Az}$ ajánlásokban változó a kezelés dózisa és tartama is. Ha 10 g, 18 g vagy egyénre szabott nagyobb dózisú 
(300-400 mg/ttkg) immunglobulint adtak intravénásan, 3 hetente 6 alkalommal, amíg a beteg immunglobulinszintje nem normalizálódott, a kezelés hatásosnak és költséghatékonynak is bizonyult. A nagyobb dózisú profilaxis hatékonyabb volt [14, 15].

Az alábbiakban 3 klinikai vizsgálat eltérő eredményeit ismertetjük.

1. Molica S, et al. [13]. Cím magyarul: alacsony dózisú intravénás immunglobulinnal (IVIG) végzett fertőzések elleni profilaxis krónikus lymphoid leukaemiánál. Egy crossover tanulmány eredményei (8. táblázat). A betegkiválasztás feltételei a következők voltak: olyan betegek kerültek bevonásra, akiknek IgG-je kevesebb volt, mint 6 $\mathrm{g} / \mathrm{l}$, és/vagy legalább egy súlyos fertőzésen estek át a vizsgálat előtti 6 hónapban. Ezek alapján 42 beteg került véletlenszerü kiválasztásra. Két csoportra osztották a betegeket. Az egyik csoport 4 hetente $300 \mathrm{mg} / \mathrm{ttkg}$ IVIGet kapott 6 hónapig, a másik csoport nem kapott IVIGkezelést. 30 beteg volt, akik befejezték a 6 hónapig tartó kezelést. 6 hónap után a kezelt betegek csoportját felosztották szintén két csoportra, melyből az egyik csoport továbbra is kapta a kezelést. A 12 hónapos kezelési ido"szakot 17 beteg fejezte be.

Eredmények: Szignifikánsan kevesebb fertőzés volt azoknál a betegeknél, akik 6 hónapig kapták az IVIG-et, vagy megfigyelés alatt álltak. Ugyanazt alkalmazták a 17 betegnél, akik 12 hónapos megfigyelés alatt álltak, vagy IVIG-profilaxist kaptak. Érdekes módon az IgG-szint normalizálódása 25-ből 17 betegnél történt meg; ez átlagosan $41,8 \%$, ami nem állt párhuzamban az infekciók csökkenésével. Az infekciók elleni védőhatás a kis dózisú IVIG mellett is megfigyelhető volt. Javára volt azoknak a betegeknek, akik befejezték a 12 vagy 6 hónapos IVIGprofilaxist; azonban még ez az alacsony dózisú kezelés sem költséghatékony útja az infekciók megelőzésének CLL-ben szenvedő betegeknél.

2. Griffiths H, et al. [14]. Cím magyarul: Alacsony fokozatú, B-sejtes tumorban szenvedő betegeknél végzett immunglobulin-pótló terápiával végrehajtott crossover tanulmány (9. táblázat). A betegeket a következő feltételekkel választották ki: akinél kevesebb volt az IgGszint, mint 3,5 g/l, és/vagy legalább egy súlyos fertőzésen esett át (összesen 12 beteget vontak be a tanulmányba). A betegek vagy $0,2-0,6 \mathrm{~g} / \mathrm{ttkg}$ IVIG-et vagy placebót kaptak, 3 hetenként 12 hónapig. Ezután áttértek az alternatív készítményre (a placebóra) egy újabb évre. Azoknál a betegeknél fordult elő súlyos bakteriális fertőzés, akiknek az IgG-szintje 6,4 g/1-nél kevesebb volt. Összefoglalva: A súlyos bakteriális fertőzések száma jelentősen kisebb volt ( $\mathrm{p}=0,001$; Mainland crossoveres módszer) azokban a hónapokban, amelyekben a betegek IgG-t kaptak. A súlyos bakteriális fertőzések olyan trendet mutattak, mely a $<6,4 \mathrm{~g} / 1 \mathrm{IgG}$-szinttel társítható $(\mathrm{p}=0,46$; Fisher-féle egzakt teszt). Arra a következtetésre jutottak, hogy bármilyen korú betegeknek, akiknek állandó a betegségük, valamint visszatérő bakteriális fertőzéstörténetük és hypogammaglobulinaemiá-
8. táblázat

A fertőzések megelózése etiológiai és súlyossági szempontból azoknál a betegeknél, akik 6 és akik 12 hónapos IVIG-kezelést kaptak, vagy tapasztalati terápiában részesültek

\begin{tabular}{lcc|cc}
\hline & $\begin{array}{c}\text { 6 hónapos időszak } \\
(\mathrm{n}=30)\end{array}$ & $\begin{array}{c}12 \text { hónapos időszak } \\
(\mathrm{n}=17)\end{array}$ \\
\hline & Tapasztalati & IVIG & Tapasztalati & IVIG \\
\hline $\begin{array}{l}\text { Bakteriális fertózés } \\
- \text { Súlyos }\end{array}$ & 4 & 2 & 2 & 1 \\
- Enyhe & 18 & 8 & 16 & 7 \\
\hline
\end{tabular}

Gombás fertőzés

\begin{tabular}{lrcrc}
- Súlyos & 1 & 0 & 0 & 0 \\
\hline $\begin{array}{l}\text { Vírusfertózés } \\
- \text { Enyhe }\end{array}$ & 2 & 1 & 4 & 1 \\
\hline Jelentéktelen & 12 & 4 & 6 & 1 \\
\hline Betegek fertőzés nélkül & 9 & $20^{*}$ & 6 & $13^{* *}$ \\
\hline Az összes hónap száma & 321 & 292 & 206 & 215 \\
\hline
\end{tabular}

Molica $S$, et al. [13]

IVIG = intravénás immunglobulin

${ }^{*} \mathrm{p}<0,01$

${ }^{* *} \mathrm{p}<0,02$

9. táblázat |A fertőzés típusa és súlyossága összehasonlítva az IVIG-kezelést kapott és nem kapott betegeknél

\begin{tabular}{lcc}
\hline & IVIG & $\begin{array}{c}\text { Fiziológiás } \\
\text { sóoldat }\end{array}$ \\
\hline Nem volt fertőzés & 6 & 1 \\
\hline Súlyos & 0 & \\
- Bakteriális fertőzés & 1 & 9 \\
- Vírusfertőzés & 1 & 1 \\
- Gombás fertőzés & 2 & 0 \\
- Összesen & & 10
\end{tabular}

Mérsékelt

- Bakteriális fertőzés

- Vírusfertőzés

- Gombás fertőzés

0

- Ismeretlen

1

- Összesen

Jelentéktelen

Teljes terápiás ciklus ( 3 hetente)

Griffiths H, et al. [14]

IVIG = intravénás immunglobulin

juk van, valószínúsíthetően előnyük származik a hosszú távú intravénás IgG-profilaxisból. A stabil betegséggel rendelkező betegeknél a visszatérő bakteriális fertőzések számának és a hypogammaglobulinaemia csökkenésének jót tesz a tartósan alkalmazott IVIG-profilaxis.

3. Gamm H, et al. [15]. Cím magyarul: Intravénás immunglobulin krónikus lymphocytás leukaemiában (10. táblázat). Randomizált kettős vaktanulmány, me- 
Fertőzések előfordulása 36 betegen; a nagy és kis dózisú IVIGgel végzett kettős vak-profilaxistanulmány eredményei

\begin{tabular}{lcc}
\hline & $\begin{array}{c}\text { Nagy dózis } \\
(500 \mathrm{mg} / \mathrm{ttkg})\end{array}$ & $\begin{array}{c}\text { Kis dózis } \\
(250 \mathrm{mg} / \mathrm{ttkg})\end{array}$ \\
\hline Bakteriális fertőzés & 7 & 9 \\
- Enyhe & 2 & 2 \\
- Súlyos & 5 & 7 \\
\hline Vírusfertőzés & 5 & 9 \\
- Enyhe & 4 & 7 \\
- Súlyos & 0 & 2 \\
\hline Gombás fertőzés - enyhe & 1 & 1 \\
\hline Ismeretlen & 10 & 3 \\
- Enyhe & 9 & 1 \\
- Súlyos & 1 & 2 \\
\hline Összesen & 23 & 22 \\
\hline Súlyos fertőzés betegenként - & $0-33$ & $0-38$ \\
évente & & \\
\hline
\end{tabular}

Gamm H, et al. [15]

$\mathrm{CLL}=$ krónikus lymphoid leukaemia; IVIG = intravénás immunglobulin

lyet 36 betegen végeztek el, akik vagy $500 \mathrm{mg} / \mathrm{kg}$, vagy $250 \mathrm{mg} / \mathrm{kg}$ IVIG-kezelésben 4 hetente részesültek, hogy megállapítsák a szükséges dózismennyiséget. Nem volt szignifikáns különbség a két kezelési csoport között, és azt találták, hogy a CLL-betegek azonos mértékben voltak védettek az alacsony vagy a magas szintú IVIGkezeléssel elért protektív hatás között [16].

Végül számunkra a legfontosabb tanulság az, hogy megfelelö indikáció esetén (alacsony IgG-szint és/vagy visszatéró infekciók) feltétlenül szü̈séges az immunglobulin pótlása, mely kivédi a CLL-betegek morbiditását és ennek szöpődményeként, mortalitását. Nagy hiba és szégyen, hogy erre vonatkozóan még mindig nincs egyértelmüen elfogadott-sem magyar, sem nemzetközi-irányelv.

Anyagi támogatás: A közlemény megírása, illetve a kapcsolódó kutatómunka anyagi támogatásban nem részesült.

Szerzői munkamegosztás: Minden társszerző jelentősen hozzájárult a kézirat szerkezetének felépítéséhez, az irodalmi adatok kritikus értelmezéséhez, ezek alapján egységesen tettük meg ajánlásainkat a csökkent immunglobulinszint korrekciójára és ezzel a fokozott morbiditás és mortalitás kivédésére. A cikk végleges változatát valamennyi szerző elolvasta, javította és jóváhagyta.

Érdekeltségek: A szerzőknek nincsenek érdekeltségeik a kézirat megírásával kapcsolatban, sem személyes, sem pénzügyi, sem egyéb vonatkozásban.

\section{Irodalom}

[1] Riches JC, Gribben JG. Understanding the immunodeficiency in chronic lymphocytic leukemia: potential clinical implications. Hematol Oncol Clin North Am. 2013; 27: 207-235.

[2] Wintrobe MM, Hasenbush LL. Chronic leukemia: the early phase of chronic leukemia, the results of treatment and the effects of complicating infections; a study of eighty-six adults. Arch Intern Med (Chic). 1939; 64: 701-718.

[3] Hallek M, Fischer K, Fingerle-Rowson G, et al. Addition of rituximab to fludarabine and cyclophosphamide in patients with chronic lymphocytic leukaemia: a randomised, open-label, phase 3 trial. Lancet 2010; 376: 1164-1174.

[4] Andersen MA, Vojdeman FJ, Andersen MK, et al. Hypogammaglobulinemia in newly diagnosed chronic lymphocytic leukemia is a predictor of early death. Leuk Lymphoma 2016; 57: 15921599.

[5] Forconi F, Moss P. Perturbation of the normal immune system in patients with CLL. Blood 2015; 126: 573-581.

[6] Stelmach P, Robak T. Pathogenesis, prophylaxis and treatment of infections in patients with chronic lymphocytic leukemia. Postepy Hig Med Dosw (Online). 2013; 67: 560-568. [Article in Polish]

[7] Gurbity Pálfi T, Fésüs V, Bödör Cs, et al. State of the art molecular diagnostics and therapy of chronic lymphocytic leukaemia in the era of new targeted therapies. [A krónikus lymphocytás leukaemia korszerű molekuláris diagnosztikája és kezelése az új célzott terápiák korszakában.] Orv Hetil. 2017; 158: 1620-1629. [Hungarian]

[8] Fésüs V, Marosvári D, Kajtár B, et al. TP53 mutation analysis in chronic lymphocytic leukaemia. [A TP53-mutáció-analízis jelentősége krónikus lymphocytás leukaemiában.] Orv Hetil. 2017; 158: 220-228. [Hungarian]

[9] Boughton BJ, Jackson N, Lim S, et al. Randomized trial of intra venous immunoglobulin prophylaxis for patients with chronic lymphocytic leukaemia and secondary hypogammaglobulinaemia. Clin Lab Haematol. 1995; 17: 75-80.

[10] Jurlander J, Geisler CH, Hansen MM. Treatment of hypogammaglobulinaemia in chronic lymphocytic leukaemia by low-dose intravenous gammaglobulin. Eur J Haematol. 1994; 53: 114118.

[11] Dhalla F, Lucas M, Schuh A, et al. Antibody deficiency secondary to chronic lymphocytic leukemia: should patients be treated with prophylactic replacement immunoglobulin? J Clin Immunol. 2014; 34: 277-282.

[12] Compagno N, Malipiero G, Cinetto F, et al. Immunoglobulin replacement therapy in secondary hypogammaglobulinemia. Front Immunol. 2014; 5: 626.

[13] Molica S, Musto P, Chiurazzi F, et al. Prophylaxis against infections with low-dose intravenous immunoglobulins (IVIG) in chronic lymphocytic leukemia. Results of a crossover study. Haematologica 1996; 81: 121-126.

[14] Griffiths H, Brennan V, Lea J, et al. Crossover study of immunoglobulin replacement therapy in patients with low-grade B-cell tumors. Blood 1989; 73: 366-368.

[15] Gamm H, Huber C, Chapel H, et al. Intravenous immune globulin in chronic lymphocytic leukaemia. Clin Exp Immunol. 1994; 97(Suppl 1): 17-20.

[16] Petrányi Gy, Padányi Á, Kotlán B, et al. Immunomodulation effect of the intravenous immunoglobulin (IVIG) blood product. [Az intravénás immunglobulin (IVIG) vérkészítmény immunmodulációs hatása.] Focus Med. 2006; 8: 8-12. [Hungarian]

(Losonczy Hajna dr., Pécs, Ifjúság útja 13., 7624 e-mail: hajna.losonczy@hotmail.com) 